\title{
Polymerization of vinyl ethers initiated by dendritic cations using flow microreactors
}

\section{$\operatorname{AUTHOR}(\mathrm{S}):$}

Nagaki, Aiichiro; Takumi, Masahiro; Tani, Yosuke; Yoshida, Jun-ichi

\section{CITATION:}

Nagaki, Aiichiro ...[et al]. Polymerization of vinyl ethers initiated by dendritic cations using flow microreactors. Tetrahedron 2015, 71(35): 5973-5978

\section{ISSUE DATE:}

2015-09

URL:

http://hdl.handle.net/2433/202006

\section{RIGHT:}

(c) 2015. This manuscript version is made available under the CC-BY-NC-ND 4.0 license

http://creativecommons.org/licenses/by-nc-nd/4.0/; The full-text file will be made open to the public on 4 June 2017 in accordance with publisher's 'Terms and Conditions for Self-Archiving'; この論文は出版社版でありません。引用の際に は出版社版をご確認ご利用ください。; This is not the published version. Please cite only the published version. 


\section{Graphical Abstract}

To create your abstract, type over the instructions in the template box below.

Fonts or abstract dimensions should not be changed or altered.

\section{Polymerization of Vinyl Ethers Initiated by} Dendritic Cations Using Flow Microreactors

Leave this area blank for abstract info.

Aiichiro Nagaki, Masahiro Takumi, Yosuke Tani, and Jun-ichi Yoshida*

Department of Synthetic Chemistry and Biological Chemistry, Graduate School of Engineering, Kyoto University, Nishikyo-ku, Kyoto 615-8510, Japan.

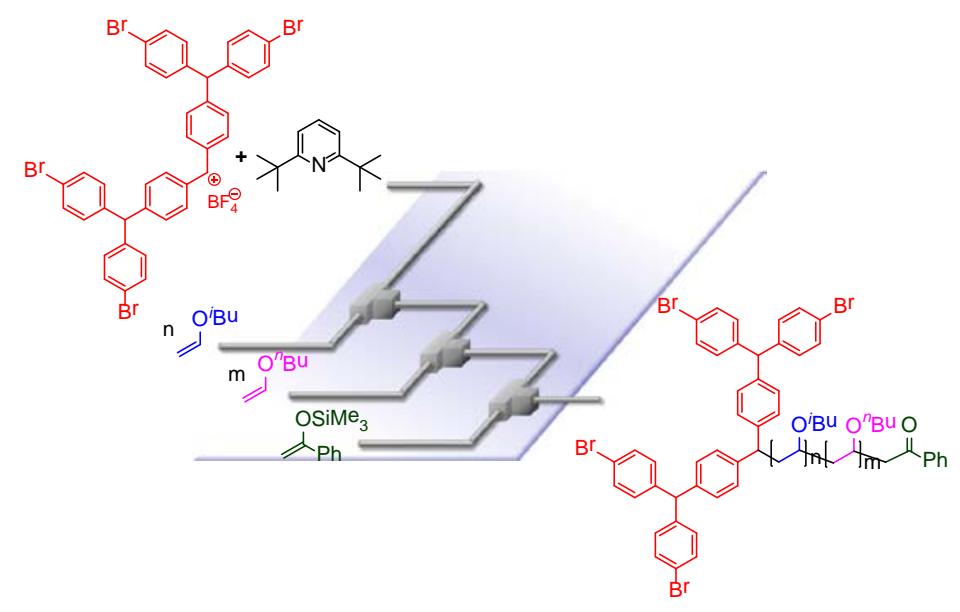




\title{
Polymerization of Vinyl Ethers Initiated by Dendritic Cations Using Flow Microreactors
}

\author{
Aiichiro Nagaki, Masahiro Takumi, Yosuke Tani, and Jun-ichi Yoshida* \\ ${ }^{a}$ Department of Synthetic Chemistry and Biological Chemistry, Graduate School of Engineering, Kyoto University, Nishikyo-ku, Kyoto 615-8510, Japan.
}

\section{ARTICLE INFO}

\section{Article history:}

Received

Received in revised form

Accepted

Available online

\section{Keywords:}

\section{microreactors}

dendritic cation

polymerization

block copolymerization

\section{ABSTRACT}

Cationic polymerization of vinyl ethers initiated by an electrogenerated dendritic diarylcarbenium ion in the presence of 2,6-di-tert-butylpyridine was developed using a flow microreactor. The carbocationic polymer end generated by polymerization of isobutyl vinyl ether was effectively trapped by various nucleophiles such as trimethyl(1-phenylvinyloxy)silane and allyltrimethylsilane to give polymers with very narrow molecular weight distribution. The block copolymerization of two vinyl ethers followed by trapping with nucleophiles was successfully accomplished to give structurally well-defined macromolecules.

2015 Elsevier Ltd. All rights reserved.

\section{Introduction}

Linear-dendritic polymers have emerged as a new important type of macromolecules in materials science, ${ }^{1}$ and the ambivalent characteristics of their architecture offer unique/new possibilities for numerous potential applications. ${ }^{2}$ Linear-dendritic polymers can be prepared based on three strategies: ${ }^{3}(1)$ coupling strategy: ${ }^{4}$ coupling of a dendrimer and a functional linear polymer chain, (2) chain-first strategy: ${ }^{5}$ the synthesis of a terminally functional polymer chain and the subsequent construction of a dendrimer, and (3) dendron-first strategy: ${ }^{6}$ the synthesis of a dendrimer followed by polymerization initiated at the dendrimer. Especially the dendron-first approach is very useful because the dendrimers can be constructed by a convergent synthetic route such as coupling of prefabricated branched units.

We have developed the cation pool method in which organic cations are electrochemically ${ }^{7}$ generated and accumulated in solution in the absence of nucleophiles and are used for the reactions with subsequently added nucleophiles. ${ }^{8}$ The method has been successfully applied to various organic cations including $N$ acyliminium ions, alkoxycarbenium ions, and diarylcarbenium ions. We have also developed an iterative process for making dendtritic structures based on the cation pool method; a sequence consisting of the electrochemical generation of a diarylcarbenium ion (activation) followed by the reaction with (diphenylmethyl)trimethylsilane as a building block (coupling) is repeated to effect convergent synthesis of dendritic molecules (Figure 1). ${ }^{9}$ Notably, dendritic diarylcarbenium ions react with unfunctionalized polystyrenes to give dendronized polymers. $^{10}$

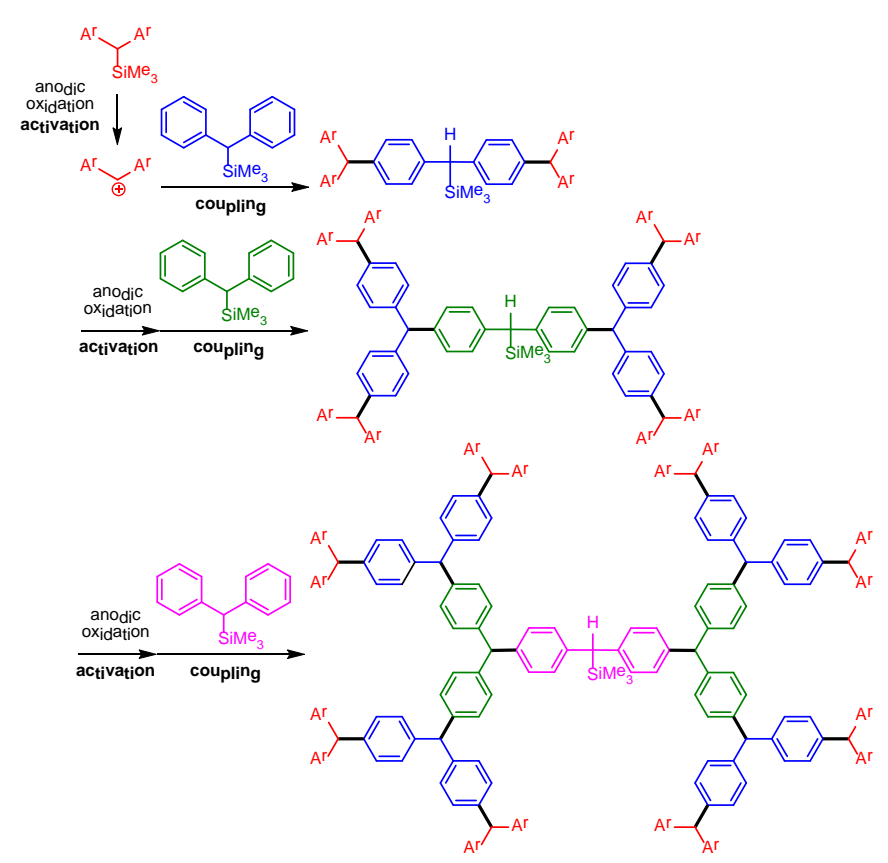

Figure 1. An iterative process for making dendritic structures based on the cation pool method. 


\section{Tetrahedron}

Chemical synthesis in flow microreactors ${ }^{11,12,13}$ has attracted a great deal of attention and the applications to polymerization of vinyl monomers have been extensively studied. ${ }^{14}$ For example, controlled cationic polymerization ${ }^{15,16}$ of vinyl ethers and controlled anionic polymerization ${ }^{17,18}$ of styrenes, alkyl methacrylates, and tert-butyl acrylate using flow microreactors have been reported in the literature. The molecular weight and the molecular weight distribution can be strictly controlled by virtue of the characteristic features of flow microreactors such as fast mixing, fast heat transfer, and precise residence time control.

Based on these achievements, the following working hypothesis came to our mind. Use of dendritic diarylcarbenium ions as initiators of controlled cationic polymerization in flow microreactors leads to the formation of linear-dendritic polymers bearing living polymer ends which can be trapped with nucleophiles (dendron-first strategy). The method would serve as a powerful and straightforward way of synthesizing structurally well-defined linear-dendritic polymers. However, to the best of our knowledge, such an approach has not yet been reported so far, although studies using ring-opening polymerizations ${ }^{6 c}$ and living radical polymerizations ${ }^{6 \mathrm{~b}, 6 \mathrm{~d}, 6 \mathrm{e}}$ have been reported. The concept works, and we report herein the results of this proof-of-principle study.

\section{Results and Discussion}

\section{Cationic Polymerization of Isobutyl Vinyl Ether Initiated by} a Dendritic Diarylcarbenium Ion Pool

We chose to study diarylcarbenium ion $2^{19}$ as a model of a dendritic initiator of the cationic polymerization. Cation 2 was generated by low temperature electrochemical oxidation of $\mathbf{1}$, which has a silyl group as an electroauxiliary ${ }^{20}$ for the selective oxidation and peripheral bromo functionalities for future functionalization (Figure 2).

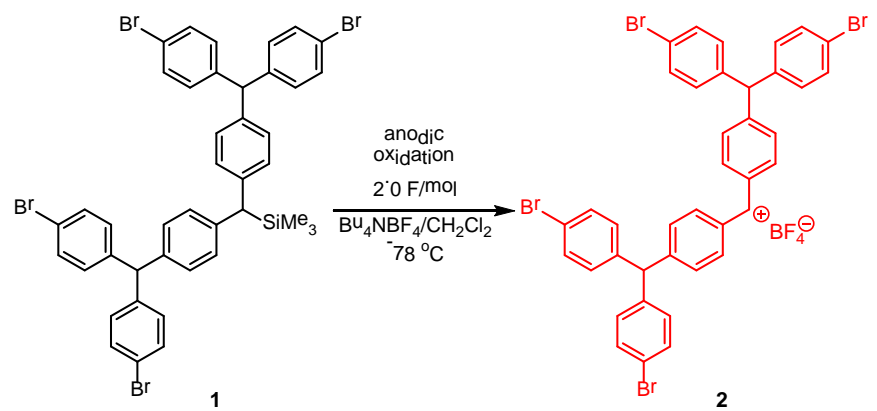

Figure 2. Generation of diarylcarbenium ion 2.

First, we examined the polymerization of isobutyl vinyl ether using diarylcarbenium ion $\mathbf{2}$ in a flow microreactor system composed of two T-shaped micromixers (M1 and M2) and two microtube reactors (R1 and R2) (Figure 3). The flow microreactor system was dipped in a cooling bath $\left(-78{ }^{\circ} \mathrm{C}\right)$. A solution of isobutyl vinyl ether $\left(0.50 \mathrm{M}\right.$ in $\left.\mathrm{CH}_{2} \mathrm{Cl}_{2}, 10 \mathrm{~mL} / \mathrm{min}\right)$ and a solution of $2\left(0.050 \mathrm{M}\right.$ in $\left.\mathrm{CH}_{2} \mathrm{Cl}_{2}, 5 \mathrm{~mL} / \mathrm{min}\right)$ were mixed using M1 $(\phi=250 \mu \mathrm{m})$. The mixed solution was introduced to $\mathbf{R 1}(\phi=1000 \mu \mathrm{m}, \mathrm{L}=25 \mathrm{~cm})$, where the polymerization took place. The polymerization was terminated by adding a solution of trimethyl(1-phenylvinyloxy)silane $\left(1.0 \mathrm{M}\right.$ in $\left.\mathrm{CH}_{2} \mathrm{Cl}_{2}, 5 \mathrm{~mL} / \mathrm{min}\right)$ at $\mathbf{M} 2(\phi=500 \mu \mathrm{m})$ and $\mathbf{R} 2(\phi=1000 \mu \mathrm{m}, \mathrm{L}=50 \mathrm{~cm})$ to obtain the end-functionalized polymer $\mathbf{3}$. When the polymerization was carried out in the presence of a proton trapping agent, the agent was added to a solution of $\mathbf{2}$ prior to the polymerization.

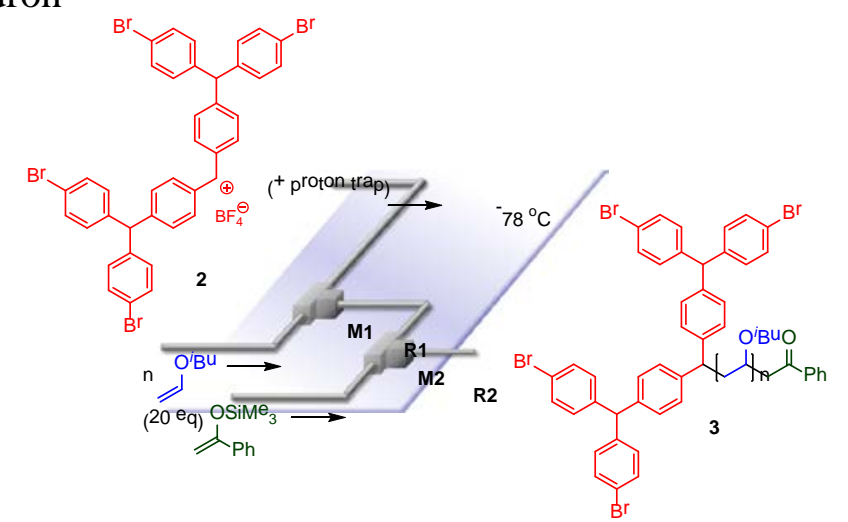

Figure 3. Flow microreactor for cationic polymerization of isobutyl vinyl ether initiated by diarylcarbenium ion 2 in the absence or presence of a proton trapping agent at $-78{ }^{\circ} \mathrm{C}$. Tshaped micromixers: M1 and M2. Microtube reactors: R1 and R2.

Figure 4 shows MALDI-TOF mass spectra of the resulting polymers. The polymer produced in the absence of a proton trapping agent is contaminated with a significant amount of the polymer obtained by proton-initiated polymerization (Figure 4 (a)).

Polymerizations in the presence of 1,8bis(dimethylamino)naphthalene as a proton trapping agent resulted in much low yields of polymer $\mathbf{3}$, although $\mathbf{3}$ was obtained in good yields in the absence of a proton trapping agent (Table 1). In contrast, polymerizations using 2,6-di-tertbutylpyridine as a proton trapping agent gave $\mathbf{3}$ in good yields.

Table 1. Cationic polymerization of isobutyl vinyl ether initiated by diarylcarbenium ion 2 in the absence or presence of a proton trapping agent using a flow microreactor system.

\begin{tabular}{|c|c|c|c|c|}
\hline \multicolumn{2}{|l|}{ proton trapping agent } & \multicolumn{3}{|c|}{$\mathrm{Mn}^{a} \quad \mathrm{MW} / \mathrm{Mn}^{a}$ yield $(\%)$} \\
\hline & & 5200 & 108 & quarit \\
\hline & $0.3 e_{q}$ & 13400 & 110 & 61 \\
\hline & $0.5 \mathrm{eq}_{\mathrm{q}}$ & 12100 & 119 & 22 \\
\hline & $10 \mathrm{e}_{\mathrm{q}}$ & 16100 & $1: 11$ & 6 \\
\hline & $0.3 e_{q}$ & 6600 & 106 & 87 \\
\hline & $0.5 \mathrm{eq}_{\mathrm{q}}$ & 8100 & 105 & 83 \\
\hline & $10 e_{q}$ & 9000 & 1.05 & 90 \\
\hline
\end{tabular}

Notably, the use of 2,6-di-tert-butylpyridine as a proton trapping agent resulted in a dramatic decrease in the amount of the polymer formed by the proton initiation, although the yield of the polymer was not decreased significantly (Figure 4 (b)). The result indicates that protons, which were presumably generated by the electrolysis, were effectively trapped with 2,6-di-tertbutylpyridine. Therefore, the desired polymer $\mathbf{3}$ with narrow molecular weight distribution $(\mathrm{Mw} / \mathrm{Mn}=1.05)$ was obtained, indicating that diarylcarbenium ion $\mathbf{2}$ worked well as an initiator. In contrast, the polymerization in the presence of 2,6-di-tertbutylpyridine $(0.5 \mathrm{eq})$ using a batch macro reactor was examined. The addition of $2\left(0.050 \mathrm{M}\right.$ in $\left.\mathrm{CH}_{2} \mathrm{Cl}_{2}\right)$ and 2,6-di-tertbutylpyridine $\left(0.025 \mathrm{M}\right.$ in $\left.\mathrm{CH}_{2} \mathrm{Cl}_{2}\right)(5 \mathrm{~mL}, 5.0 \mathrm{~mL} / \mathrm{min})$ to a solution of isobutyl vinyl ether $\left(10 \mathrm{~mL}, 0.50 \mathrm{M}\right.$ in $\left.\mathrm{CH}_{2} \mathrm{Cl}_{2}\right)$ in a glass flask (25 mL) gave the polymer in $84 \%$ yield after quenching with trimethyl(1-phenylvinyloxy)silane $(1.0 \mathrm{~mL}, 1.0$ $\mathrm{M}$ in $\mathrm{CH}_{2} \mathrm{Cl}_{2}$ ), but the molecular weight distribution was not 
narrow $(\mathrm{Mn}=26600, \mathrm{Mw} / \mathrm{Mn}=1.45)$. The reverse addition gave rise to only a slight improvement of the similar molecular weight distribution control (97\% yield, $\mathrm{Mn}=7560, \mathrm{Mw} / \mathrm{Mn}=1.29)$. The simultaneous addition did not work (96\% yield, $\mathrm{Mn}=11200$, $\mathrm{Mw} / \mathrm{Mn}=1.59)$. Thus, it is reasonable to consider that the characteristic features of a flow microreactor system such as fast mixing enables the diarylcarbenium ion intiated polymerization in a highly controlled manner.

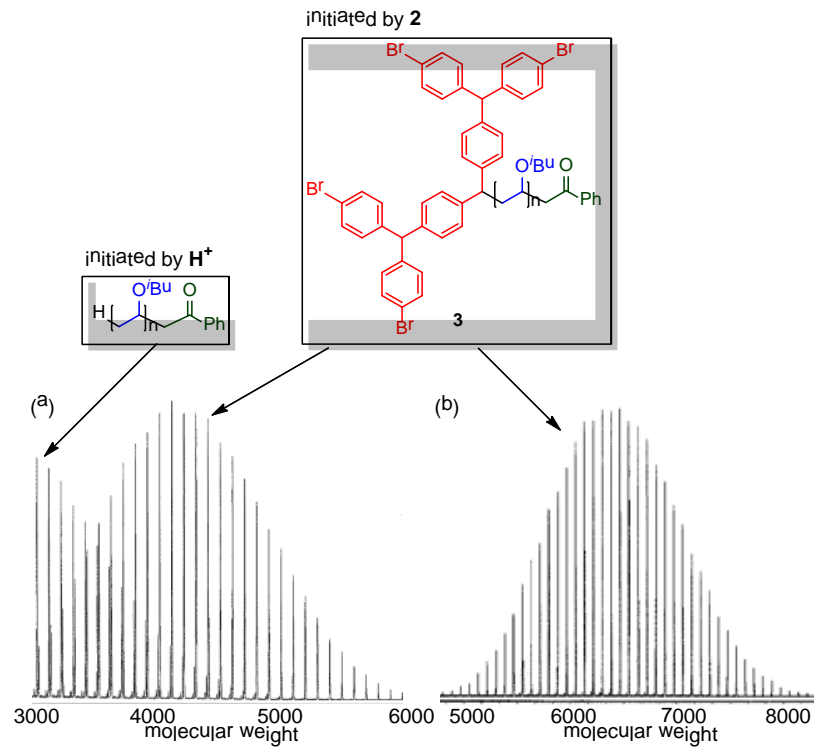

Figure 4. MALDI-TOF mass spectra of the polymers obtained by (a) the polymerization in the absence of a proton trapping agent and (b) the polymerization in the presence of 2,6-di-tertbutylpyridine (0.5 eq).

Next, the effect of mixing was examined. Generally, the mixing speed depends on the flow rate and the inner diameter of a micromixer. ${ }^{21}$ As shown in Table 2, the molecular weight distribution strongly depends on the flow rate and the inner diameter of micromixer M1. The polydispersity index (Mw/Mn) decreased with the increase in the total flow rate in M1. The $\mathrm{Mw} / \mathrm{Mn}$ also decreased with a decrease in the inner diameter of M1. The results indicate that extremely fast mixing is responsible for narrow molecular weight distribution $(\mathrm{Mw} / \mathrm{Mn}<1.10)$.

Table 2. Effect of mixing for cationic polymerization of isobutyl vinyl ether in the presence of 2,6-di-tert-butylpyridine (0.5 eq) initiated by diarylcarbenium ion 2 using a flow microreactor.

\begin{tabular}{|c|c|c|c|c|}
\hline $\begin{array}{c}\text { inner diameter of M1 } \\
(\mu \mathrm{m})\end{array}$ & $\begin{array}{c}\text { total flow rate in M1 } \\
(\mathrm{mL} / \mathrm{min})\end{array}$ & $\mathrm{Mn}^{\mathrm{a}}$ & $\mathrm{MW} / \mathrm{Mn}^{a}$ & yield (\%) \\
\hline 250 & 30 & 8600 & 203 & 55 \\
\hline 250 & 90 & 7000 & $1: 11$ & 99 \\
\hline 250 & $15^{\circ} 0$ & 8100 & 105 & 83 \\
\hline 500 & $15^{\circ} 0$ & 6100 & $1 \cdot 16$ & 95 \\
\hline
\end{tabular}

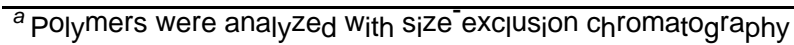
calibrated with polystyrene

In addition to trimethyl(1-phenylvinyloxy)silane, allyltrimethylsilane was also used as a terminating agent to obtain the end-functionalized polymer $\mathbf{4}$ in a good yield with narrow molecular weight distribution $(\mathrm{Mw} / \mathrm{Mn}=1.06)$. The ${ }^{1} \mathrm{H}$ NMR spectra of polymers $\mathbf{3}$ and $\mathbf{4}$ are shown in Figure 5 . The two methine protons $\left(\mathrm{H}^{\mathrm{a}}\right)$ derived from 2 was clearly observed at $\delta=5.37 \mathrm{ppm}$ (d, $J=2.8 \mathrm{~Hz}$ ) (for $\mathbf{3}$ and $\mathbf{4})$. The end group such as an aryl group (for 3: aromatic protons, $\delta=7.45,7.55$ and 7.96 $\mathrm{ppm}$ ) and as an allyl group (for 4: olefinic protons, $\delta=5.01-5.06$ and 5.78-5.84 ppm) were observed. The relative intensities of these protons based on the methine proton $\left(\mathrm{H}^{\mathrm{a}}\right)$ indicate that the carbocationic polymer end was effectively trapped by the added nucleophiles. Therefore, the present method serves as an effective method for synthesis of end functionalized lineardendritic polymers.

(a)

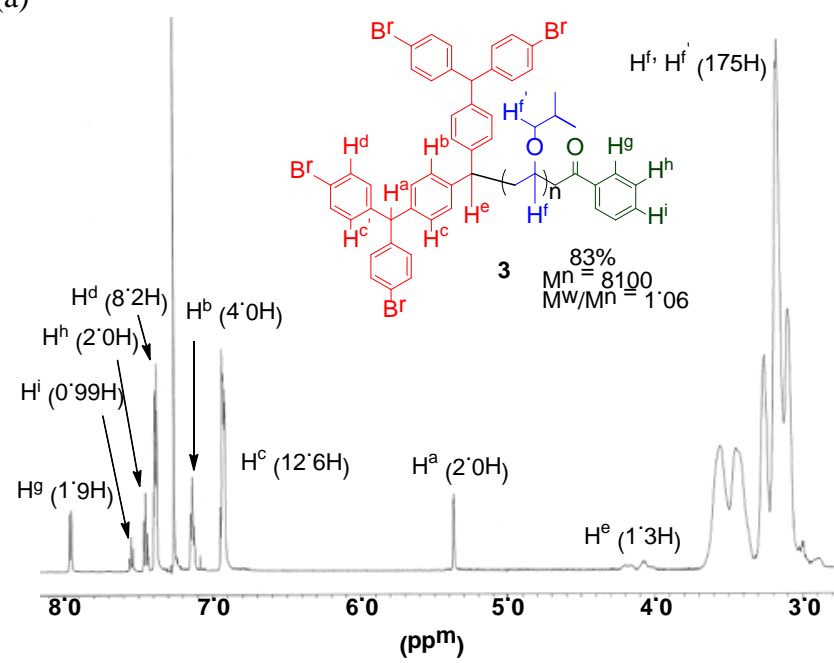

(b)

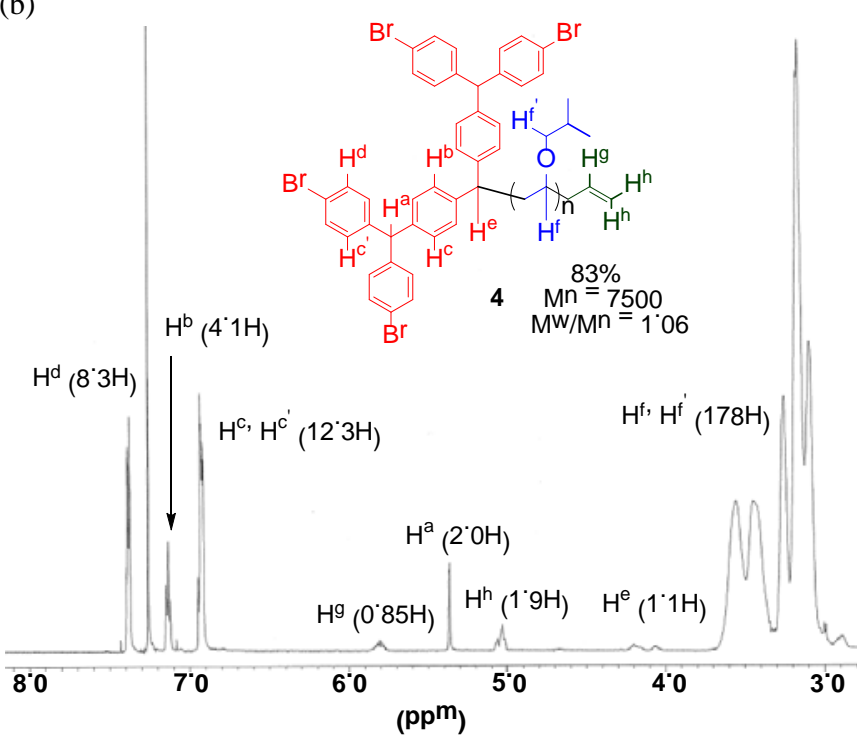

Figure 5. ${ }^{1} \mathrm{H}$ NMR spectra of end-functionalized linear-dendritic polymers; (a) 3 and (b) 4.

\section{Cationic Block Copolymerization of Vinyl Ethers Initiated by a Diarylcarbenium Ion Pool Using an Integrated Flow Microreactor System}

Next, the block copolymerization of isobutyl vinyl ether and n-butyl vinyl ether was carried out using an integrated flow microreactor systems consisting of three micromixers (M1, M2, and $\mathbf{M 3}$ ) and three microtube reactors (R1, R2, and R3) shown in Figure 6. A solution of $2(0.050 \mathrm{M})$ and 2,6-di-tert-butylpyridine $(0.025 \mathrm{M})$ in $\mathrm{CH}_{2} \mathrm{Cl}_{2}(5 \mathrm{~mL} / \mathrm{min})$ and a solution of isobutyl vinyl ether $\left(0.50 \mathrm{M}\right.$ in $\left.\mathrm{CH}_{2} \mathrm{Cl}_{2}, 10 \mathrm{~mL} / \mathrm{min}\right)$ were mixed using $\mathbf{M 1}(\phi=$ $250 \mu \mathrm{m})$. The mixed solution was introduced to $\mathbf{R} \mathbf{1}$, where the polymerization was carried out. Then, the solution of $n$-butyl vinyl ether (1.0 M in $\mathrm{CH}_{2} \mathrm{Cl}_{2}, 5 \mathrm{~mL} / \mathrm{min}$ ) was introduced to $\mathbf{M} 2$ $(\phi=500 \mu \mathrm{m})$, which was connected to $\mathbf{R} 2(\phi=1000 \mu \mathrm{m}, \mathrm{L}=50$ 


\section{Tetrahedron}

$\mathrm{cm}\left(-50^{\circ} \mathrm{C}\right)$ or $\left.\phi=1000 \mu \mathrm{m}, \mathrm{L}=100 \mathrm{~cm}\left(-78^{\circ} \mathrm{C}\right)\right)$ where the second polymerization took place. The polymerization was terminated by introducing a solution of trimethyl(1phenylvinyloxy)silane (1.0 M in $\left.\mathrm{CH}_{2} \mathrm{Cl}_{2}, 5 \mathrm{~mL} / \mathrm{min}\right)$ to $\mathbf{M} 3$ ( $\phi=$ $500 \mu \mathrm{m})$ and $\mathbf{R} 3(\phi=1000 \mu \mathrm{m}, \mathrm{L}=50 \mathrm{~cm})$. GPC traces of the polymers $\mathbf{5}$ obtained under various conditions are shown in Figure 7.

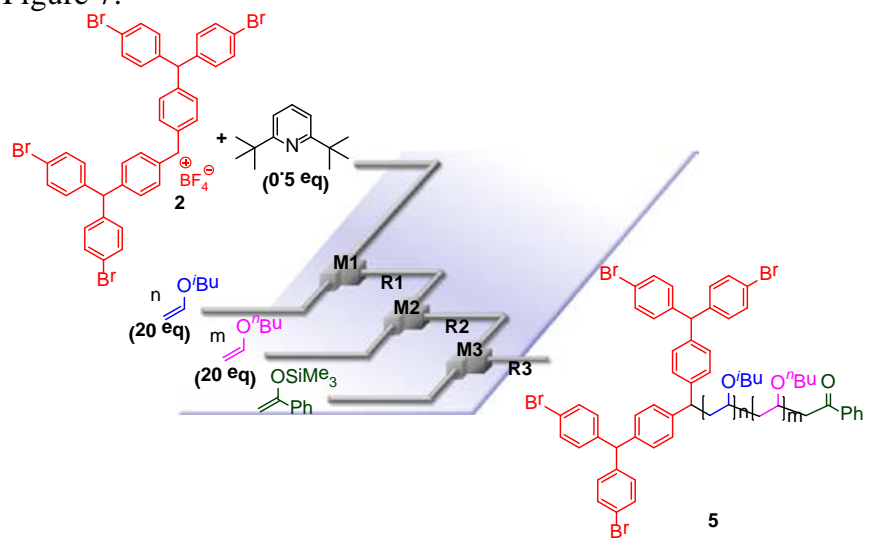

Figure 6. Integrated flow microreactor system for cationic block copolymerization of isobutyl vinyl ether and $n$-butyl vinyl ether initiated by a diarylcarbenium ion 2 in the presence of 2,6-di-tertbutylpyridine. T-shaped micromixers: M1, M2, and $\mathbf{M} 3$. Microtube reactors: R1, R2, and R3.

The $\mathrm{Mn}$ increased when the second monomer solution was added at $-50{ }^{\circ} \mathrm{C}$ as shown in Figure 7 (a), indicating that the polymerization of the second monomer took place. However, the bimodal molecular weight distribution even with short residence times in R1 indicates decomposition of the reactive polymer chain end generated by the first polymerization. However, the block copolymerization was successfully carried out without significant decomposition of the living polymer end at $-78{ }^{\circ} \mathrm{C}$ with a short residence time in R1 (0.79 s) to obtain $\mathbf{5}$ in $95 \%$ yield with narrow molecular weight distribution $(\mathrm{Mw} / \mathrm{Mn}=1.08)$ as shown in Figure 7 (b).

(a)

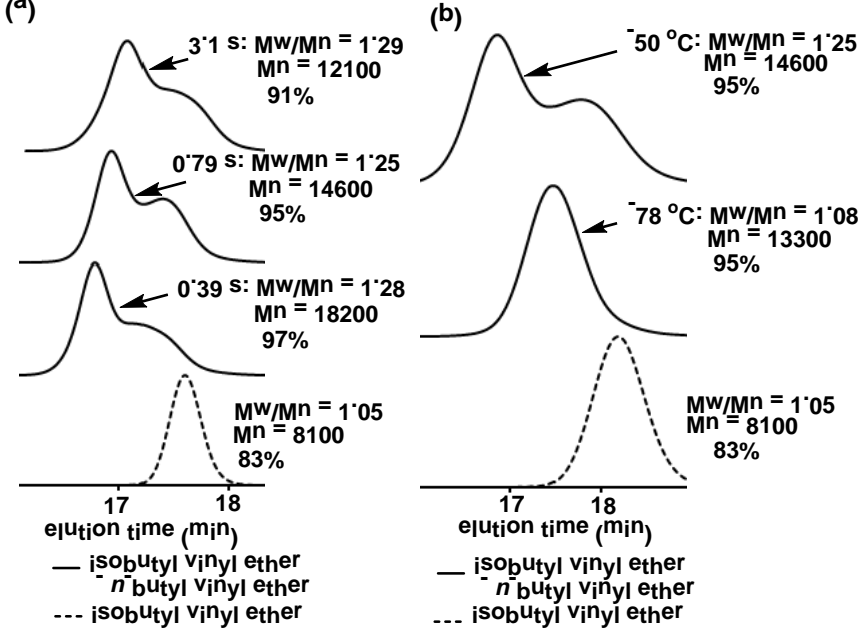

Figure 7. Size exclusion chromatography traces of the cationic block copolymerization of isobutyl vinyl ether and $n$-butyl vinyl ether in the integrated flow microreactor system (a) at $-50{ }^{\circ} \mathrm{C}$ with varying the residence time in $\mathbf{R} \mathbf{1}$ and (b) with the residence time of $0.79 \mathrm{~s}$ in $\mathbf{R} \mathbf{1}$ with varying the temperature.

The ${ }^{1} \mathrm{H}$ NMR (Figure 8) and MALDI-TOF-MS analyses of the resulting polymer 5 revealed that end functional groups were introduced almost quantitatively (See the Supporting Information for details). Notably, the block copolymer $\mathbf{5}$ bears the bromo groups at the peripheral of the dendritic part, which can be used for further transformations such as Hartwig-Buchwald amination $^{22}$.

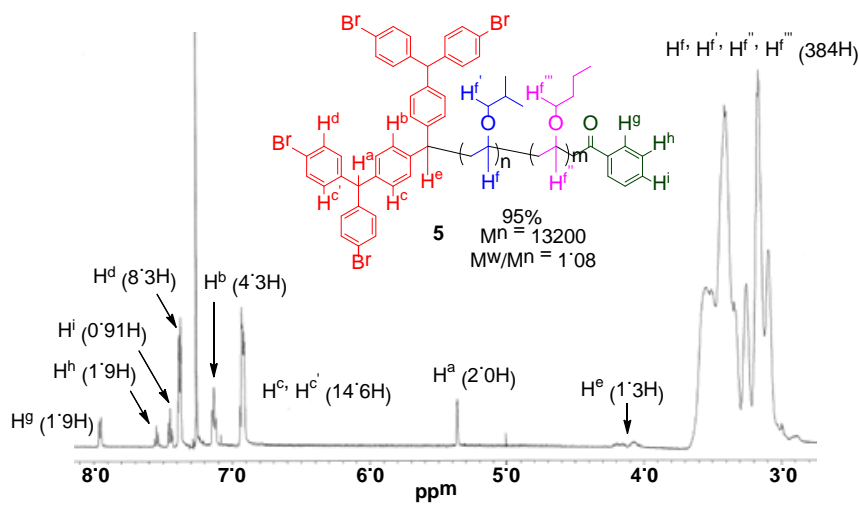

Figure 8. ${ }^{1} \mathrm{H}$ NMR spectrum of end functionalized block copolymers (5).

\section{Conclusion}

In conclusion, controlled cationic polymerization of vinyl ethers initiated by a cation pool of a dendritic diarylcarbenium ion was successfully achieved using the flow microreactor system. Extremely fast mixing is responsible for narrow molecular weight distribution and the polymer end can be used as living reactive species for the subsequent reactions with a nucleophiles and block copolymerization. The observations illustrated here open a new possibility in the synthesis of lineardendritic polymers. Further applications of the present method are under investigation in our laboratory.

\section{Experimental section}

\section{General}

${ }^{1} \mathrm{H}$ and ${ }^{13} \mathrm{C}$ NMR spectra were recorded in $\mathrm{CDCl}_{3}$ on JEOL ECA-600P $\left({ }^{1} \mathrm{H} 600 \mathrm{MHz}\right.$ and $\left.{ }^{13} \mathrm{C} 150 \mathrm{MHz}\right)$. Chemical shifts are recorded using a methine signal of $\mathrm{CHCl}_{3}$ for ${ }^{1} \mathrm{H}$ NMR (7.26 ppm) and ${ }^{13} \mathrm{C}$ NMR (77.0 ppm) unless otherwise noted. MALDITOF mass spectra were recorded on Bruker ultraflex. Preparative gel permeation chromatography (GPC) was performed on Japan Analytical Industry LC-918. Dichloromethane was washed with water, distilled from $\mathrm{P}_{2} \mathrm{O}_{5}$, redistilled from dried $\mathrm{K}_{2} \mathrm{CO}_{3}$ to remove a trace amount of acid, and stored over molecular sieves 4A. Isobutyl vinyl ether and $n$-butyl vinyl ether were distilled under reduced pressure from $\mathrm{CaH}_{2}$ twice. $\mathrm{Bu}_{4} \mathrm{NBF}_{4}$ was dried at $25{ }^{\circ} \mathrm{C} / 1 \mathrm{mmHg}$ for 12 hours. 1 was prepared according to reported procedure ${ }^{19}$. Unless otherwise noted, all materials were obtained from commercial suppliers and were used without further purification. All solutions used for flow reactions were prepared under the argon atmosphere using dry solvents.

Stainless steel (SUS304) T-shaped micromixers with inner diameter of 250 and $500 \mu \mathrm{m}$ were manufactured by Sanko Seiki Co., Inc. Stainless steel (SUS316) microtube reactors with inner diameter of $1000 \mu \mathrm{m}$ were purchased from GL Sciences. The micromixers and microtube reactors were connected with stainless steel fittings (GL Sciences, 1/16 OUW). The flow microreactor system was dipped in a cooling bath to control the temperature. The solutions were introduced to the flow microreactor system using Harvard Model 11 syringe pumps equipped with gastight syringes purchased from SGE. 


\section{Molecular Weight and Molecular Weight Distribution}

The molecular weight (Mn) and molecular weight distribution (Mw/Mn) were determined in THF at $40{ }^{\circ} \mathrm{C}$ with a Shodex GPC-101 equipped with two LF-804L columns (Shodex) and an RI detector using a Polystyrene (PolySt) standard sample for calibration.

\section{Electrochemical Generation of the Cation Pool of 2 from 1}

The anodic oxidation was carried out in an H-type divided cell (4G glass filter) equipped with a carbon felt anode (Nippon Carbon JF-20-P7, ca. $320 \mathrm{mg}$, dried at $250{ }^{\circ} \mathrm{C} / 1 \mathrm{mmHg}$ for $2.5 \mathrm{~h}$ before use) and a platinum plate cathode (20 mm x $10 \mathrm{~mm})$. A $0.3 \mathrm{M}$ solution of $\mathbf{1}$ (1.55 g, $1.75 \mathrm{mmol}$ ) in $\mathrm{Bu}_{4} \mathrm{NBF}_{4} / \mathrm{CH}_{2} \mathrm{Cl}_{2}$ (35 $\mathrm{mL}$ ) was placed in the anodic chamber, and a $0.3 \mathrm{M}$ solution of $\mathrm{Bu}_{4} \mathrm{NBF}_{4} / \mathrm{CH}_{2} \mathrm{Cl}_{2}$ (35 mL) and trifluoromethanesulfonic acid (230 $\mu \mathrm{L}, 2.60 \mathrm{mmol}$ ) were placed in the cathodic chamber. The constant current electrolysis $(40 \mathrm{~mA})$ was carried out at $-78{ }^{\circ} \mathrm{C}$ with magnetic stirring until $2.0 \mathrm{~F} / \mathrm{mol}$ of electricity was consumed.

Cationic Polymerization of Isobutyl Vinyl Ether Using Trimethyl(1-phenylvinyloxy)silane as a Terminating Agent in a Flow Microreactor System.

After electrolysis the resulting solution of $2\left(6 \mathrm{~mL},-78^{\circ} \mathrm{C}\right)$ was transferred to a $20 \mathrm{~mL}$ flask at $-78^{\circ} \mathrm{C}$, and a proton trapping agent was added. The resulting solution was stirred for $10 \mathrm{~min}$ at $-78{ }^{\circ} \mathrm{C}$. A flow microreactor system consisting of two T-shaped micromixers (M1 and M2), two microtube reactors (R1 and R2), and three pre-cooling units (P1 (inner diameter $\phi=1000 \mu \mathrm{m}$, length $\mathrm{L}=25 \mathrm{~cm}), \mathbf{P} 2(\phi=1000 \mu \mathrm{m}, \mathrm{L}=50 \mathrm{~cm})$ and $\mathbf{P 3}(\phi=$ $1000 \mu \mathrm{m}, \mathrm{L}=50 \mathrm{~cm}$ )) was used for polymerization. A solution of isobutyl vinyl ether $\left(0.50 \mathrm{M}\right.$ in $\left.\mathrm{CH}_{2} \mathrm{Cl}_{2}\right)$ and a solution of 2 containing the trapping agent were introduced to M1. The mixed solution was passed through R1 $(\phi=1000 \mu \mathrm{m}, \mathrm{L}=25 \mathrm{~cm})$ and was introduced to $\mathbf{M} 2(\phi=500 \mu \mathrm{m})$. A solution of trimethyl(1phenylvinyloxy)silane (1.0 $\mathrm{M}$ in $\mathrm{CH}_{2} \mathrm{Cl}_{2}$ ) was introduced to $\mathbf{M} 2$ $(\phi=500 \mu \mathrm{m})$, and the resulting solution was passed through $\mathbf{R} 2$ $(\phi=1000 \mu \mathrm{m}, \mathrm{L}=50 \mathrm{~cm})$. After a steady state was reached, the product solution was collected (10 s) and treated with ${ }^{i} \mathrm{Pr}_{2} \mathrm{NH}$. The reactions were carried out by changing the amount of a proton trapping agent, the flow rate, and the inner diameter of M1. The solvent was removed under reduced pressure and the residue was filtered through a silica gel column $(2 \times 3 \mathrm{~cm})$ using $\mathrm{Et}_{2} \mathrm{O}$ as an eluent to remove $\mathrm{Bu}_{4} \mathrm{NBF}_{4}$. The filtrate was concentrated to obtain a polymer product, which was analyzed with size exclusion chromatography. Purified with preparative GPC gave 3 .

\section{Block Copolymerization of Isobutyl Vinyl Ether and n-Butyl Vinyl Ether Using Trimethyl(1-phenylvinyloxy)silane as a Terminating Agent in an Integrated Flow Microreactor System}

After electrolysis the resulting solution of $2\left(6 \mathrm{~mL},-78^{\circ} \mathrm{C}\right)$ was transferred to a $20 \mathrm{~mL}$ flask at $-78{ }^{\circ} \mathrm{C}$ and 2,6-di-tertbutylpyridine ( 0.5 equiv based on $\mathbf{1}$ ) was added. The resulting solution was stirred for $10 \mathrm{~min}$ at $-78{ }^{\circ} \mathrm{C}$. A flow microreactor system consisting of three T-shaped micromixers (M1, M2, and M3), three microtube reactors (R1, R2, and R3), and four precooling units (P1 (inner diameter $\phi=1000 \mu \mathrm{m}$, length $\mathrm{L}=25$ $\mathrm{cm}), \mathbf{P 2}(\phi=1000 \mu \mathrm{m}, \mathrm{L}=50 \mathrm{~cm}), \mathbf{P} 3(\phi=1000 \mu \mathrm{m}, \mathrm{L}=50 \mathrm{~cm})$, and $\mathbf{P 4}(\phi=1000 \mu \mathrm{m}, \mathrm{L}=50 \mathrm{~cm}))$ was used for polymerization. A solution of isobutyl vinyl ether $\left(0.50 \mathrm{M}\right.$ in $\left.\mathrm{CH}_{2} \mathrm{Cl}_{2}, 10 \mathrm{~mL} / \mathrm{min}\right)$ and a solution of 2 containing 2,6-di-tert-butylpyridine (5 $\mathrm{mL} / \mathrm{min})$ were introduced to $\mathbf{M 1}(250 \mu \mathrm{m})$. The mixed solution was passed through $\mathbf{R} 1$ and was introduced to $\mathbf{M} 2(\phi=500 \mu \mathrm{m})$. A solution of $n$-butyl vinyl ether (1.0 $\mathrm{M}$ in $\left.\mathrm{CH}_{2} \mathrm{Cl}_{2}, 5 \mathrm{~mL} / \mathrm{min}\right)$ was introduced to $\mathbf{M} 2(\phi=500 \mu \mathrm{m})$. The mixed solution was passed through $\mathbf{R} 2$ and was introduced to $\mathbf{M} 3(\phi=500 \mu \mathrm{m})$. A solution of trimethyl(1-phenylvinyloxy)silane $\left(1.0 \mathrm{M}\right.$ in $\mathrm{CH}_{2} \mathrm{Cl}_{2}$, $5 \mathrm{~mL} / \mathrm{min})$ was introduced to $\mathbf{M} 3(\phi=500 \mu \mathrm{m})$, and the resulting solution was passed through $\mathbf{R} 3(\phi=1000 \mu \mathrm{m}, \mathrm{L}=50 \mathrm{~cm})$. After a steady state was reached, the product solution was collected (10 s) and treated with ${ }^{i} \mathrm{Pr}_{2} \mathrm{NH}$. The reactions were carried out by changing temperature and the residence time in $\mathbf{R} \mathbf{2}$ and $\mathbf{R} 3$. The solvent was removed under reduced pressure and the residue was filtered through a silica gel column $(2 \times 3 \mathrm{~cm})$ using $\mathrm{Et}_{2} \mathrm{O}$ as an eluent to remove $\mathrm{Bu}_{4} \mathrm{NBF}_{4}$. The filtrate was concentrated to obtain a polymer product, which was analyzed with size exclusion chromatography. The polymer product was purified with preparative GPC to obtain 5.

\section{Supplementary data}

Supplementary data related to this article can be found, in the online version, at http://dx.doi.org/

\section{Acknowledgments}

This work was partially supported by the Grant-in-Aid for Scientific Research (S) (no. 26220804) and Scientific Research (B) (no. 26288049). The authors thank Prof. Mitsuo Sawamoto and Dr. Takaya Terashima of for fruitful discussions.

\section{References and notes}

1 (a) Tomalia, D. A.; Fréchet, J. M. J. J. Polym. Sci. Part A Polym. Chem. 2002, 40 2719. (b) Gitsov, I. J. Polym. Sci. Part A: Polym. Chem. 2008, 46, 5295. (c) Wurm, F.; Frey, H. Prog. Poly. Sci. 2011, 36, 1.

2 Some selected examples: (a) Fréchet, J. M. J.; Gitsov, I.; Monteil, T.; Rochat, S.; Sassi, J. F.; Vergelati, C.; Yu, D. Chem. Mater. 1999, 11, 1267. (b) Gillies, E. R.; Jonsson, T. B.; Fréchet, J. M. J. J. Am. Chem. Soc. 2004, 126, 11936. (c) Adeli, M.; Zarnegar, M.; Dadkhah, A.; Hossieni, R.; Salimi, F.; Kanani, A. J. Appl. Polym. Sci. 2007, 104, 267. (d) Stover, T. C.; Kim, Y. C.; Lowe, T. L.; Kester, M. Biomaterials 2008, 29, 359. (e) Simonyan, A.; Gitsov, I. Langmuir 2008, 24, 11431

3 Wurm, F.; Frey, H. Prog. Poly. Sci. 2011, 36, 1.

4 Some selected examples: (a) Gitsov, I.; Wooley, K. L.; Fréchet, J. M. J. Angew. Chem. Int. Ed. 1992, 31, 1200. (b) Gitsov, I.; Fréchet, J. M. J. Macromolecules 1994, 27, 7309. (c) Kim, Y. S.; Gil, E. S.; Lowe, T. L. Macromolecules 2006, 39 7805. (d) Hua, C.; Peng, S. M.; Dong, C. M. Macromolecules 2008, 41, 6686

5 Some selected examples: (a) Chapman, T. M.; Hillyer, G. L.; Mahan, E. J.; Shaffer, K. A. J. Am. Chem. Soc. 1994, 116, 11195. (b) Iyer, J.; Fleming, K. Hammond, P. T. Macromolecules 1998, 31, 8757. (c) Choi, J. S.; Joo, D. K.; Kim, C. H.; Kim, K.; Park, J. S. J. Am. Chem. Soc. 2000, 122, 474. (d) Carnahan, M. A.; Middleton, C.; Kim, J.; Kim, T.; Grinstaff, M. W. J. Am. Chem. Soc. 2002, 124, 5291. (e) Degoricija, L.; Carnahan, M. A.; Johnson, C. S.; Kim, T.; Grinstaff, M. W. Macromolecules 2006, 39, 8952.

6 Some selected examples: (a) Gitsov, I.; Ivanova, P. T.; Fréchet, J. M. J. Macromol. Rapid Commun. 1994, 15, 387. (b) Leduc, M. R.; Hawker, C. J.; Dao, J.; Fréchet, J. M. J. J. Am. Chem. Soc. 1996, 118, 11111. (c) Mecerreyes, D.; Dubois, PH.; Jérôme, R.; Hedrick, J. L.; Hawker, C. J. J. Polym. Sci. Part A Polym. Chem. 1999, 37, 1923. (d) Emrick, T.; Hayes, W.; Fréchet, J. M. J. J. Polym. Sci. Part A Polym. Chem. 1999, 37, 3748. (e) Pyun, J.; Tang, C.; Kowalewski, T.; Fréchet, J. M. J.; Hawker, C. J. Macromolecules 2005, 38, 2674. (f) Gitsov, I.; Simonyan, A.; Vladimirov, N. G. J. Polym. Sci. Part A Polym. Chem. 2007, 45, 5136.

7 Recent reviews on organic electrochemistry: (a) Moeller, K. D. Tetrahedron 2000, 56, 9527. (b) Sperry, J. B.; Wright, D. L. Chem. Soc. Rev. 2006, 35, 605. (c) Yoshida, J.; Kataoka, K.; Horcajada, R.; Nagaki, A. Chem. Rev. 2008, 108, 2265

8 (a) Yoshida, J.; Suga, S.; Suzuki, S.; Kinomura, N.; Yamamoto, A.; Fujiwara, K. J. Am. Chem. Soc. 1999, 121, 9546. (b) Suga, S.; Suzuki, S.; Yamamoto, A. Yoshida, J. J. Am. Chem. Soc. 2000, 122, 10244. (c) Suga, S.; Okajima, M.; Fujiwara, K.; Yoshida, J. J. Am. Chem. Soc. 2001, 123, 7941. (d) Suga, S.; Suzuki, S.; Yoshida, J. J. Am. Chem. Soc. 2002, 124, 30. (e) Suga, S.; Watanabe, M.; Yoshida, J. J. Am. Chem. Soc. 2002, 124, 14824. (f) Yoshida, J.; Suga, S. 


\section{Tetrahedron}

Chem. Eur. J. 2002, 8, 2651. (g) Suga, S.; Nagaki, A.; Yoshida, J. Chem. Commun. 2003, 354. (h) Suga, S.; Nagaki, A.; Tsutsui, Y.; Yoshida, J. Org. Lett. 2003, 5, 945 (i) Suga, S.; Nishida, T.; Yamada, D.; Nagaki, A.; Yoshida, J. J. Am. Chem. Soc. 2004, 126, 14338. (j) Suga, S.; Itami, K.; Yoshida, J. J. Am. Chem. Soc. 2005, 127, 6930. (k) Maruyama, T.; Suga, S.; Yoshida, J. J. Am. Chem. Soc. 2005, 127, 7324. (l) Nagaki, A.; Togai, M.; Suga, S.; Aoki, N.; Mae, K.; Yoshida, J. J. Am. Chem. Soc. 2005, 127, 11666. (m) Suga, S.; Matsumoto, K.; Ueoka, K.; Yoshida, J. J. Am. Chem. Soc. 2006, 128, 7710. (n) Maruyama, T.; Mizuno, Y.; Shimizu, S.; Suga, S.; Yoshida, J. J. Am. Chem. Soc. 2007, 129 , 1902. (o) Nokami, T.; Shibuya, A.; Tsuyama, H.; Suga, S.; Bowers, A. A.; Crich, D.; Yoshida, J. J. Am. Chem. Soc. 2007, 129, 10922. (p) Okajima, M.; Soga, S.; Watanabe, T.; Terao, K.; Nokami, T.; Suga, S.; Yoshida, J. Bull. Chem. Soc. Jpn. 2009, 82, 594. (q) Terao, K.; Watanabe, T.; Suehiro, T.; Nokami, T.; Yoshida, J. Tetrahedron Lett. 2010, 51, 4107. (r) Ashikari, Y.; Shimizu, A.; Nokami, T.; Yoshida, J. J. Am. Chem. Soc. 2013, 135, 16070. (s) Ashikari, Y.; Nokami, T.; Yoshida, J. J. Am. Chem. Soc. 2011, 133, 11840. (t) Morofuji, T.; Shimizu, A.; Yoshida, J. J. Am. Chem. Soc. 2014, 136, 4496.

9 (a) Nokami, T.; Ohata, K.; Inoue, M.; Tsuyama, H.; Shibuya, A.; Soga, K.; Okajima, M.; Suga, S.; Yoshida, J. J. Am. Chem. Soc. 2008, 130, 10864. (b) Nokami, T.; Watanabe, T.; Musya, N.; Suehiro, T.; Morofuji, T.; Yoshida, J. Tetrahedron 2011, 67, 4664.

10 Nokami, T.; Watanabe, T.; Musya, N.; Morofuji, T.; Tahara, K.; Tobe, Y.; Yoshida, J. Chem. Commun. 2011, 47, 5575.

11 Books on flow microreactor synthesis: (a) Ehrfeld, W.; Hessel, V.; Löwe, H. Microreactors; Wiley-VCH: Weinheim, 2000. (b) Hessel, V.; Hardt, S.; Löwe, H. Chemical Micro Process Engineering; Wiely-VCH Verlag: Weinheim, 2004 (c) Yoshida, J. Flash Chemistry. Fast Organic Synthesis in Microsystems; Wiley-Blackwell, 2008. (d) Hessel, V.; Renken, A.; Schouten, J. C.; Yoshida, J. Eds. Micro Precess Engineering; Wiley-VCH Verlag: Weinheim, 2009. (e) Wirth T. Eds. Microreactors in Organic Chemistry and Catalysis 2nd Ed. Wiley-VCH Verlag: Weinheim, 2013

12 Reviews on flow microreactor synthesis: (a) Jähnisch, K.; Hessel, V.; Löwe, H.; Baerns, M. Angew. Chem. Int. Ed. 2004, 43, 406. (b) Doku, G. N.; Verboom, W.; Reinhoudt, D. N.; van den Berg, A. Tetrahedron 2005, 61, 2733. (c) Watts, P.; Haswell, S. J. Chem. Soc. Rev. 2005, 34, 235. (d) Geyer, K.; Codée, J. D. C.; Seeberger, P. H. Chem. Eur. J. 2006, 12, 8434. (e) deMello, A. J. Nature 2006 442, 394. (f) Song, H.; Chen, D. L.; Ismagilov, R. F. Angew. Chem. Int. Ed. 2006, 45, 7336. (g) Kobayashi, J.; Mori, Y.; Kobayashi, S. Chem. Asian. J. 2006, 1, 22. (h) Brivio, M.; Verboom, W.; Reinhoudt, D. N. Lab Chip 2006, 6, 329. (i) Mason, B. P.; Price, K. E.; Steinbacher, J. L.; Bogdan, A. R.; McQuade, D. T. Chem. Rev. 2007, 107, 2300. (j) Ahmed-Omer, B.; Brandt, J. C.; Wirth, T. Org. Biomol. Chem. 2007, 5, 733. (k) Watts, P.; Wiles, C. Chem. Commun. 2007, 443 (l) Fukuyama, T.; Rahman, M. T.; Sato, M.; Ryu, I. Synlett 2008, 151. (m) Hartman, R. L.; Jensen, K. F. Lab Chip 2009, 9, 2495. (n) McMullen, J. P.; Jensen, K. F. Annu. Rev. Anal. Chem. 2010, 3, 19. (o) Yoshida, J.; Kim, H.; Nagaki, A. ChemSusChem 2011, 4, 331. (p) Wiles, C.; Watts, P. Green Chem. 2012, 14, 38. (q) Kirschining, A.; Kupracz, L.; Hartwig, J. Chem. Lett. 2012, 41, 562. (r) McQuade, D. T.; Seeberger, P. H. J. Org. Chem. 2013, 78, 6384. (s) Elvira, K. S.; i Solvas, X. C.; Wootton, R. C. R.; deMello, A. J. Nat. Chem. 2013 5, 905. (t) Pastre, J. C.; Browne, D. L.; Ley, S. V. Chem. Soc. Rev. 2013, 42, 8849. (u) Baxendale, I. R. J. Chem. Technol. Biotechnol. 2013, 88, 519.

13 Some selected recent examples: (a) Cantillo, D.; Baghbanzadeh, M.; Kappe, C. O. Angew. Chem. Int. Ed. 2012, 51, 10190. (b) Shu, W.; Buchwald, S. L. Angew. Chem. Int. Ed. 2012, 51, 5355. (c) Nagaki, A.; Moriwaki, Y.; Yoshida, J. Chem. Commun. 2012, 48, 11211. (d) Lévesque, F.; Seeberger, P. H. Angew. Chem. Int Ed. 2012, 51, 1706. (e) Basavaraju, K. C.; Sharma, S.; Maurya, R. A.; Kim, D. P. Angew. Chem. Int. Ed. 2013, 52, 6735. (f) Brancour, C.; Fukuyama, T.; Mukai, Y.; Skrydstrup, T.; Ryu, I. Org. Lett. 2013, 15, 2794. (g) Nguyen, J. D.; Reiß, B.; Dai, C.; Stephenson, C. R. J. Chem. Commun. 2013, 49, 4352. (h) Battilocchio, C.; Hawkins, J. M.; Ley, S. V. Org. Lett. 2013, 15, 2278. (i) Kleinke, A. S.; Jamison, T. F. Org. Lett. 2013, 15, 710. (j) Guetzoyan, L.; Nikbin, N.; Baxendale, I. R.; Ley, S. V. Chem. Sci. 2013, 4, 764. (k) Fuse, S.; Mifune, Y.; Takahashi, T. Angew. Chem. Int. Ed. 2014, 53, 851. (l) He, Z.; Jamison, T. F. Angew. Chem. Int. Ed. 2014, 53, 3353. (m) Nagaki, A.; Takahashi, Y.; Yoshida, J. Chem. Eur. J. 2014, 20, 7931. (n) Nagaki, A.; Ichinari, D.; Yoshida, J. J. Am. Chem. Soc. 2014, 136, 12245.

14 Reviews on polymerizations using microreactors: (a) Hessel, V.; Serra, C.; Löwe, H.; Hadziioannou, G. Chemie Ingenieur Technik 2005, 77, 1693. (b) Steinbacher, J. L.; McQuade, D. T. J. Polym. Sci., Part A: Polym. Chem. 2006 44, 6505. (c) Tonhauser, C.; Natalello, A.; Löwe, H.; Frey, H. Macromolecules 2012, 45, 9551 and references therein.

15 For living cationic polymerization: (a) Faust, R.; Schaffer T. D. Eds. Cationic Polymerization Fundamentals and Applications; American Chemical Society: Washington DC, 1997. (b) Kennedy, J. P. J. Polym. Sci. Part A 1999, 37, 2285. (c) Puska, J. E.; Kaszas, G. Prog. Polym. Sci. 2000, 403, 4.

16 Cationic polymerization using microreactors: (a) Nagaki, A.; Kawamura, K. Suga, S.; Ando, T.; Sawamoto, M.; Yoshida, J. J. Am. Chem. Soc. 2004, 126 , 14702. (b) Iwasaki, T.; Nagaki, A.; Yoshida, J. Chem. Commun. 2007, 1263. (c) Nagaki, A.; Iwasaki, T.; Kawamura, K.; Yamada, D.; Suga, S.; Ando, T.; Sawamoto, M.; Yoshida, J. Chem. Asian J. 2008, 3, 1558.

17 Living anionic polymerization: (a) Hsieh, H.; Quirk, R. P. Anionic polymerization: principles and practical applications; Marcel Dekker: New York, 1996. (b) Hong, K.; Uhrig, D.; Mays, J. W. Current Opinion in Solid State and Materials Science 1999, 4, 531. (c) Jagur-Grodzinski, J. J. Polym. Sci., Part
A: Polym. Chem. 2002, 40, 2116. (d) Smid, J. J. Polym. Sci., Part A: Polym. Chem. 2002, 40, 2101. (e) Hadjichristidis, N.; Pitsikalis, M.; Pispas, S.; Iatrou, H. Chem. Rev. 2001, 101, 3747 and references therein.

18 Anionic polymerization using microreactors: (a) Wilms, D.; Nieberle, J.; Klos, J.; Löwe, H.; Frey, H. Chem. Eng. Technol. 2007, 30, 1519. (b) Wurm, F.; Wilms, D.; Klos, J.; Löwe, H.; Frey, H. Macromol. Chem. Phys. 2008, 209, 1106. (c) Nagaki, A.; Tomida, Y.; Yoshida, J. Macromolecules 2008, 41, 6322. (d) Wilms, D.; Klos, J.; Frey, H. Macromol. Chem. Phys. 2008, 209, 343. (e) Nagaki, A.; Tomida, Y.; Miyazaki, A.; Yoshida, J. Macromolecules 2009, 42, 4384. (f) Iida, K.; Chastek, T. Q.; Beers, K. L.; Cavicchi, K. A.; Chun, J.; Fasolka, M. J. Lab Chip 2009, 9, 339. (g) Nagaki, A.; Miyazaki, A.; Yoshida, J. Macromolecules 2010, 43, 8424. (h) Tonhauser, C.; Wilms, D.; Wurm, F.; Berger-Nicoletti, E.; Maskos, M.; Löwe, H.; Frey, H. Macromolecules 2010, 43, 5582. (i) Nagaki, A.; Miyazaki, A.; Tomida, Y.; Yoshida, J. Chem. Eng. J. 2011, 167, 548. (j) Cortese, B.; Noel, T. de Croon, M. H. J. M.; Schulze, S.; Klemm, E.; Hessel, V. Macromol. React. Eng. 2012, 6, 507. (k) Tonhauser, C.; Natalello, A.; Löwe, H.; Frey, H. Macromolecules 2012, 45, 9551. (l) Nagaki, A.; Takahashi, S.; Akahori, K.; Yoshida, J. Macromol. React. Eng. 2012, 6, 467. (m) Nagaki, A.; Akahori, K.; Takahashi, Y.; Yoshida, J. J. Flow Chem. 2014, 4, 168.

19 Nokami, T.; Musya, N.; Morofuji, T.; Takeda, K.; Takumi, M.; Shimizu, A.; Yoshida, J. Beilstein J. Org. Chem. 2014, 10, 3097.

20 Yoshida, J.; Nishiwaki, K. J. Chem. Soc., Dalton Trans. 1998, 2589.

21 Ehrfeld, W.; Golbig, K.; Hessel, V.; Lowe H.; Richter, T. Ind. Eng. Chem. Res. 1999, 38, 1075 .

22 Louie, J.; Hartwig, J. F.; Fry, A. J. J. Am. Chem. Soc. 1997, 119, 11695. 